\title{
Phytoplankton community structure in the Lena Delta (Siberia, Russia) in relation to hydrography
}

\author{
A. C. Kraberg ${ }^{1}$, E. Druzhkova ${ }^{2}$, B. Heim ${ }^{3}$, M. J. G. Loeder ${ }^{1}$, and K. H. Wiltshire ${ }^{1}$ \\ ${ }^{1}$ Biologische Anstalt Helgoland, Alfred Wegener Institute for Polar and Marine Research, Kurpromenade 201, \\ 27498 Helgoland, Germany \\ ${ }^{2}$ Murmansk Marine Biological Institute, Kola Science Centre, Russian Academy of Sciences, Vladimirskaya St. 17, \\ 183010 Murmansk, Russia \\ ${ }^{3}$ Alfred Wegener Institute for Polar and Marine Research, Telegrafenberg A43, 14473 Potsdam, Germany
}

Correspondence to: A. C. Kraberg (alexandra.kraberg@awi.de)

Received: 27 October 2012 - Published in Biogeosciences Discuss.: 11 February 2013

Revised: 15 September 2013 - Accepted: 30 September 2013 - Published: 13 November 2013

\begin{abstract}
The Lena Delta in Northern Siberia is one of the largest river deltas in the world. During peak discharge, after the ice melt in spring, it delivers between $60-8000 \mathrm{~m}^{3} \mathrm{~s}^{-1}$ of water and sediment into the Arctic Ocean. The Lena Delta and the Laptev Sea coast also constitute a continuous permafrost region. Ongoing climate change, which is particularly pronounced in the Arctic, is leading to increased rates of permafrost thaw. This has already profoundly altered the discharge rates of the Lena River. But the chemistry of the river waters which are discharged into the coastal Laptev Sea have also been hypothesized to undergo considerable compositional changes, e.g. by increasing concentrations of inorganic nutrients such as dissolved organic carbon (DOC) and methane. These physical and chemical changes will also affect the composition of the phytoplankton communities. However, before potential consequences of climate change for coastal arctic phytoplankton communities can be judged, the inherent status of the diversity and food web interactions within the delta have to be established. In 2010, as part of the AWI Lena Delta programme, the phyto- and microzooplankton community in three river channels of the delta (Trofimov, Bykov and Olenek) as well as four coastal transects were investigated to capture the typical river phytoplankton communities and the transitional zone of brackish/marine conditions. Most CTD profiles from 23 coastal stations showed very strong stratification. The only exception to this was a small, shallow and mixed area running from the outflow of Bykov channel in a northerly direction parallel to the shore. Of the five stations in this area, three had a salinity of close
\end{abstract}

to zero. Two further stations had salinities of around 2 and 5 throughout the water column. In the remaining transects, on the other hand, salinities varied between 5 and 30 with depth. Phytoplankton counts from the outflow from the Lena were dominated by diatoms (Aulacoseira species) cyanobacteria (Aphanizomenon, Pseudanabaena) and chlorophytes. In contrast, in the stratified stations the plankton was mostly dominated by dinoflagellates, ciliates and nanoflagellates, with only an insignificant diatom component from the genera Chaetoceros and Thalassiosira (brackish as opposed to freshwater species). Ciliate abundance was significantly coupled with the abundance of total flagellates. A pronounced partitioning in the phytoplankton community was also discernible with depth, with a different community composition and abundance above and below the thermocline in the stratified sites. This work is a first analysis of the phytoplankton community structure in the region where Lena River discharge enters the Laptev Sea.

\section{Introduction}

The Lena River is one of the largest rivers in the world. It alone is responsible for the discharge of $20 \%$ of the total freshwater volume into the Arctic Ocean, namely the Laptev Sea (Cauwet and Sidorov, 1996). Discharge rates into the Laptev Sea are extremely variable. They are low in winter, but just after the snow and ice melt in spring, peak discharge rates surge, reaching $60-80000 \mathrm{~m}^{3} \mathrm{~s}^{-1}$ in 
June (Yang et al., 2002). The coastal Laptev Sea is therefore characterized by a complex hydrography resulting from a varying extent of the so-called region of freshwater influence (ROFI) and advection of Arctic Ocean water from the north (Gordeev, 2000). As a result of ongoing climate change, rates of permafrost thaw are also increasing, which is expected to lead to an increased discharge of the Lena into the Arctic Ocean (Lyon and Destouni, 2010). This is likely to have a major impact on coastal hydrography. Changed discharge patterns and a general rise in air and ocean temperatures could in the long-term lead to stronger stratification of coastal waters (Doney, 2006) and a changed positioning and greater stability of fronts in the transitional zone between the region of freshwater influence and the open sea. This is supported by previous paleoecological studies using palynomorph and diatom proxies, which have shown considerable fluctuations in Lena River discharge several times during the Holocene (Polyakova et al., 2006).

The Lena is considered to be the major source of organic matter entering the Laptev Sea (Gordeev et al., 1996; Kassens et al., 1998, 1999; Lobbes et al., 2000). But while coastal erosion and fluvial transports of particulate as well as dissolved organic carbon into the Buor-Khaya Gulf (Charkin et al., 2011) are normal processes, the expected increase in discharge resulting from permafrost thaw is also likely to lead to a considerable increase in delivery of inorganic nutrients (Nowinski et al., 2008), terrigenous dissolved organic carbon (DOC) and particulate organic carbon (POC) as well as methane to coastal waters (Finlay et al., 2006; Bussmann, 2013). Changes in these parameters could also have profound consequences for the resident phytoplankton communities.

More pronounced stratification, keeping cells in the better illuminated surface waters, could have considerable effects on local food webs via bottom-up effects, where inorganic nutrients fuel increased primary production which is then available for higher trophic levels (Doney, 2006). The formation of frontal systems for instance is already known to be associated with the triggering of algal blooms, and particularly in communities likely to be light limited, such as in the Arctic Ocean, increased stratification is thought to trigger greater primary production by maintaining phytoplankton cells in the well-lit surface waters for longer periods of time (Taylor and Ferrari, 2011). Moreover, it has been hypothesized that increased stratification could lead to changes in production patterns, favouring the slow-growing cyanobacteria over diatoms (Thompson et al., 2003; Oliver and Ganf, 2000; Paerl, 1996), but again no data exist yet to show what the typical phytoplankton community composition in stratified and mixed waters in the Lena Delta might be, particularly as data on the physiology of the relevant organisms are lacking.

Therefore, in order to assess potential consequences of future climate change effects such as changes in coastal water chemistry and hydrography on biological communities in the Lena Delta, it is a vital prerequisite to first describe and understand the dynamics in the present day system. In neigh- bouring rivers, e.g. the Yenisei, the diatom communities are known to some extent and are dominated by centric taxa such as several species of the genus Aulacoseira, Stephanodiscus and Cyclotella (Genkal et al., 2010). The overall diversity seemed high with more than 300 species (chlorophyceae, cyanobacteria, diatoms, dinoflagellates), e.g. in the Taz River in western Siberia (Yarushina, 2008). Microzooplankton community data are also available for the Ob River (Kopylov and Kosolapov, 2011). However, no comprehensive data are yet available for the Lena Delta except two studies by Tuschling (2000) in the Southern Laptev Sea and Sorokin and Sorokin (1996), which, however, did not refer in detail to the freshwater component of the coastal plankton, although this could make a significant contribution to local primary production and of course serve as a food source for coastal zooplankton.

Many of the above examples indicate potential factors by which the phytoplankton community in the Lena Delta might be structured. However, these effects cannot be investigated without detailed phytoplankton data from the main river channels and the coastal Laptev Sea or even a taxonomic baseline of the phytoplankton present in the area. The aims of this study were therefore to establish this baseline diversity of the coastal phytoplankton community, to investigate how community composition changes in different areas, and to examine whether community composition can be linked to basic physico-chemical parameters such as salinity and water chemistry, which will allow us to gauge future effects of permafrost thaw on the algal community.

\section{Material and methods}

\subsection{Sampling area}

Since the major focus of our analyses was to establish the differences between biological communities in different hydrographic regimes 4 coastal transects were established (see Fig. 1, Table 1) to capture these different conditions. Two transects ran in a north-southerly direction (transects 3 and 4) while two further transects ran in an easterly (transect 1) and south-easterly direction (transect 2). Transects 3 and 4 were chosen to capture the region of freshwater input running north from the mouth of Bykov channel, while transects 1 and 2 traversed the ROFI and represented the transitional zone from brackish to marine waters (see Table 1 for start and end co-ordinates of each transect). While transect 3 was very shallow (average depth $3.9 \mathrm{~m}$ ), all other transects had an average depth exceeding $10 \mathrm{~m}$ (Table 1).

Additional samples were also collected from the major navigable river channels: (1) Olenek channel (western delta), (2) Trofimov channel (central delta) and (3) Bykov channel (eastern delta, and the main source of freshwater discharge to Buor-Khaya Bay). For the purpose of this work, sampling stations in the Lena channels will be referred to as "in the 
Table 1. Geographical co-ordinates of the sampled transects. Average depth was estimated based on the depth of the individual transect stations.

\begin{tabular}{llllllll}
\hline Transect & $\begin{array}{l}\text { Start } \\
\text { Latitude }\end{array}$ & $\begin{array}{l}\text { Start } \\
\text { Longitude }\end{array}$ & $\begin{array}{l}\text { End } \\
\text { Latitude }\end{array}$ & $\begin{array}{l}\text { End } \\
\text { Longitude }\end{array}$ & $\begin{array}{l}\text { Stations/ } \\
\text { Samples }\end{array}$ & $\begin{array}{l}\text { Transect } \\
\text { length }(\mathrm{km})\end{array}$ & $\begin{array}{l}\text { Average } \\
\text { Depth }(\mathrm{m})\end{array}$ \\
\hline 1 & 71.686 & 132.423 & 72.335 & 129.734 & $7 / 21$ & 119.5 & 13.0 \\
2 & 71.5656 & 129.734 & 71.686 & 132.081 & $6 / 13$ & 60.0 & 12.0 \\
3 & 71.832 & 129.472 & 72.701 & 130.267 & $5 / 5$ & 101.5 & 3.9 \\
4 & 72.746 & 130.453 & 71.768 & 130.500 & $5 / 15$ & 102.0 & 14.4 \\
5 & 72.473 & 125.291 & 72.425 & 126.654 & $3 / 4$ & 34.7 & 10 \\
6 & 72.425 & 126.654 & 72.626 & 127.268 & $3 / 5$ & 31.0 & 16.3 \\
8 & 72.415 & 126.867 & 72.029 & 128.518 & $3 / 3$ & 70.8 & 10.7 \\
\hline
\end{tabular}

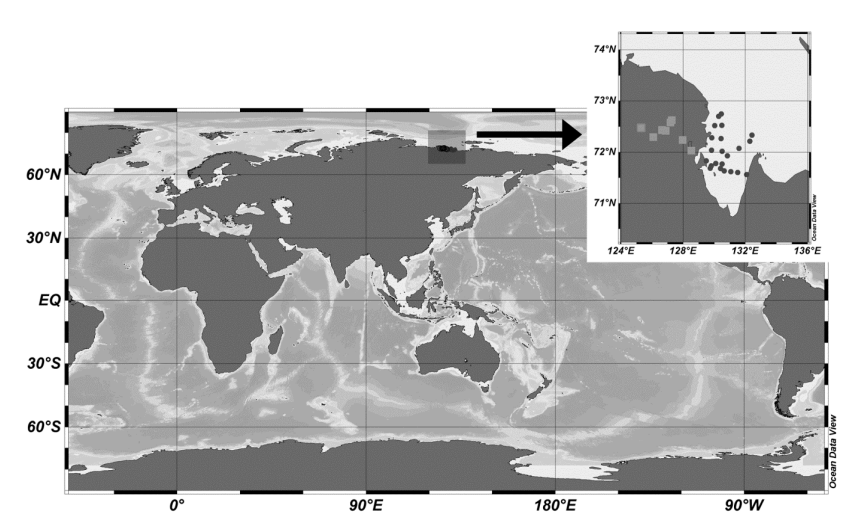

Fig. 1. Map of the Lena Delta and coastal Laptev Sea; the insert is showing the delta (light grey marks) and coastal (dark grey marks) stations sampled in 2010. Plots were generated using Ocean Data View software, v4.

delta or Delta stations", whereas transects 1-4 and the stations they comprise, will be referred to as the "coastal transects" or "coastal stations".

\subsection{Sampling methodology}

All samples were taken from on board small Russian vessels. The four coastal transects were sampled from on board the RV TB-0012 (29 July 2010-2 August 2010) and the delta transects on the RV P405 (4 August 2010-9 August 2010). At all stations water samples were taken from the surface water, water just above the seafloor and at one or several intermediate discrete water depths (subsurface samples). All subsurface sampling depths were determined on the basis of CTD (conductivity, temperature, depth) casts (Sea and Sun Technology $\mathrm{GmbH}$ ), which were carried out for all coastal transect stations (T1-T4). In the delta transects, temperature, $\mathrm{pH}$ and dissolved oxygen were measured only manually with a $\mathrm{pH}$ meter and oxygen probe (WTW, multi 350i). Where stratification could be detected, samples were then taken from above and below the thermocline (see examples in Fig. 3). In total, 66 samples were collected. From the CTD casts vertical profiles for temperature, salinity and oxygen distribution

\section{a.}

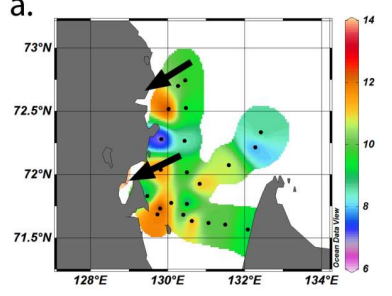

b.
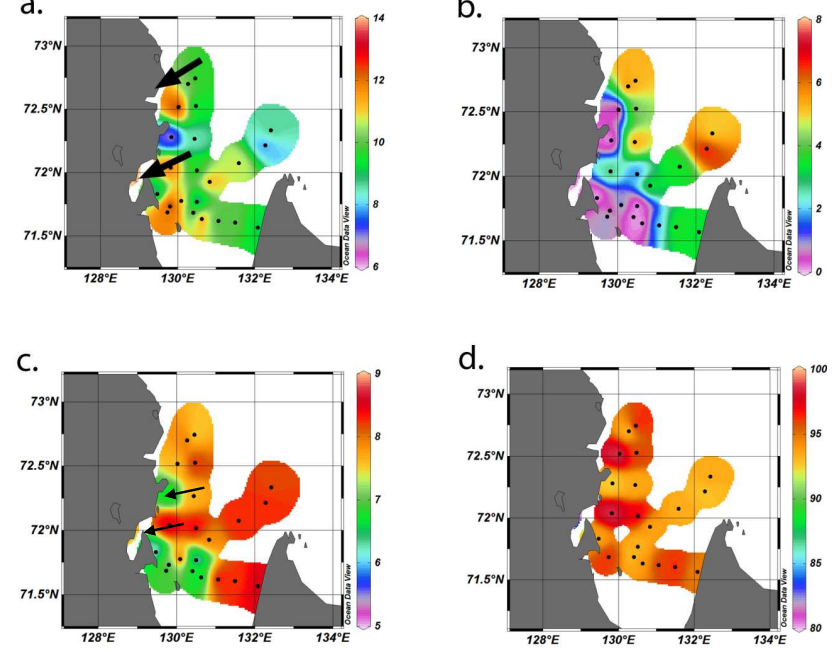

d.

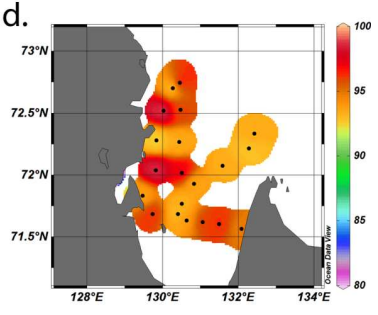

Fig. 2. ODV surface plots for (a) temperature $\left({ }^{\circ} \mathrm{C}\right)$, (b) salinity, (c) $\mathrm{pH}$, and (d) oxygen (\%) for the area covered by the 4 coastal transects, as obtained from CTD casts.

were obtained using the open source software Ocean Data View (ODV) version 4.

At all sites the same basic variables were measured: at discrete depths Niskin bottle samples were taken to sample for CHN, chlorophyll, inorganic nutrients and biological plankton samples for manual counts. To sample the micro- and mesoplankton community, more efficiently vertical hauls using plankton nets (Hydrobios, Kiel) of different mesh sizes $(20 \mu \mathrm{m}, 80 \mu \mathrm{m}, 125 \mu \mathrm{m}$ and $500 \mu \mathrm{m})$ were also carried out at all stations but only the Niskin bottle samples were analysed for the present investigation. Here we will present only the phytoplankton, nutrient and physical measurements.

\subsection{Satellite imagery}

Optical satellite data may provide additional information in space and time, visualizing optical quantities and hydrodynamical structures of surface waters such as fronts and eddies. The optical ocean colour sensor MERIS on board the ENVISAT satellite collected cloud-free satellite data of the 

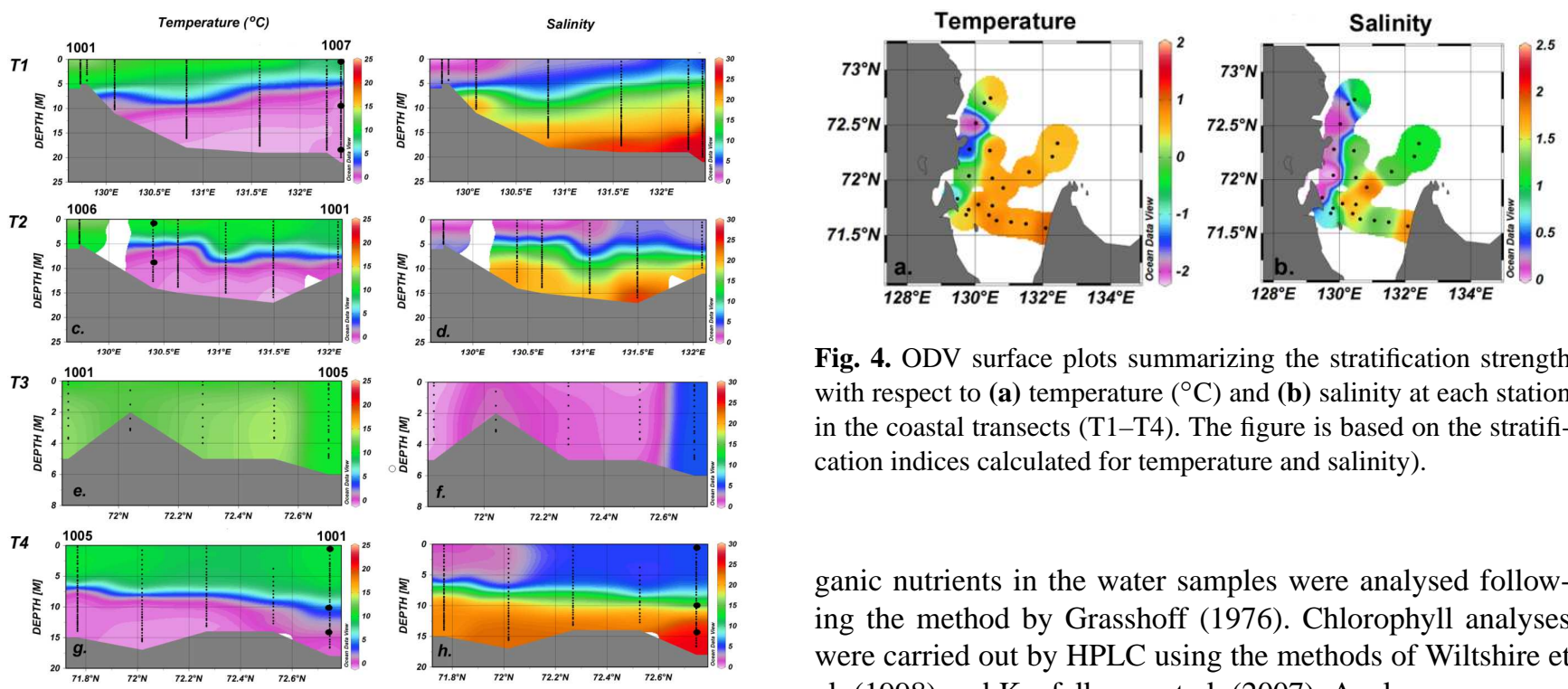

Fig. 4. ODV surface plots summarizing the stratification strength with respect to (a) temperature $\left({ }^{\circ} \mathrm{C}\right)$ and (b) salinity at each station in the coastal transects (T1-T4). The figure is based on the stratification indices calculated for temperature and salinity).

Fig. 3. Salinity and temperature profiles for the four coastal transects: $(\mathbf{a})=$ transect $1,(\mathbf{b})=$ transect $2,(\mathbf{c})=\operatorname{transect} 3,(\mathbf{d})=$ transect 4 . The larger circles indicate examples of sampling locations in relation to the thermocline in stratified water columns. Samples were taken from surface waters and above/below the thermocline.

Buor-Khaya Bay within the time frame of the ship expeditions on 3, 4 and 5 August 2010. The top-of-atmosphere data were processed towards bio- and geo-optical parameters using BEAM-VISAT $4.9^{\odot}$ with the MERIS Case-2 Regional Processor for coastal application (C2R) (Doerffer and Schiller, 2008, 2007). The diffuse attenuation coefficient, $K$, is a robust, calculated optical C2R parameter. The vertical attenuation of sunlight with depth can be described by an exponential equation, where the coefficient $K$ is measured within the photosynthetically active radiation (PAR) wave length region in $\mathrm{m}^{-1}$. The euphotic depth, $Z_{\mathrm{Eu}}$, down to which significant phytoplankton photosynthesis can occur, is the depth where the downwelling light is reduced to $1 \%$ and is calculated from $K$ :

$Z_{\mathrm{Eu}}(\lambda)=\frac{4.6}{K(\lambda)} \mathrm{m}$.

The MERIS C2R processing of the Laptev Sea region is described in more detail in Heim et al. (2013).

\subsection{Chemical analyses}

For chlorophyll analyses raw water samples were filtered over a Watman $0.45 \mu \mathrm{m}$ Nylon filter. Filters were placed in $15 \mathrm{~mL}$ plastic Falcon tubes to which $2 \mathrm{~mL}$ of HPLC grade acetone were added. The filtrate was used for inorganic nutrient analyses. It was transferred to $200 \mathrm{~mL}$ white Nalgene vessels. Both chlorophyll filters and the water for nutrient analyses were then frozen at $-20{ }^{\circ} \mathrm{C}$ and delivered to Germany in a frozen state. Upon return to the laboratory, inor- 


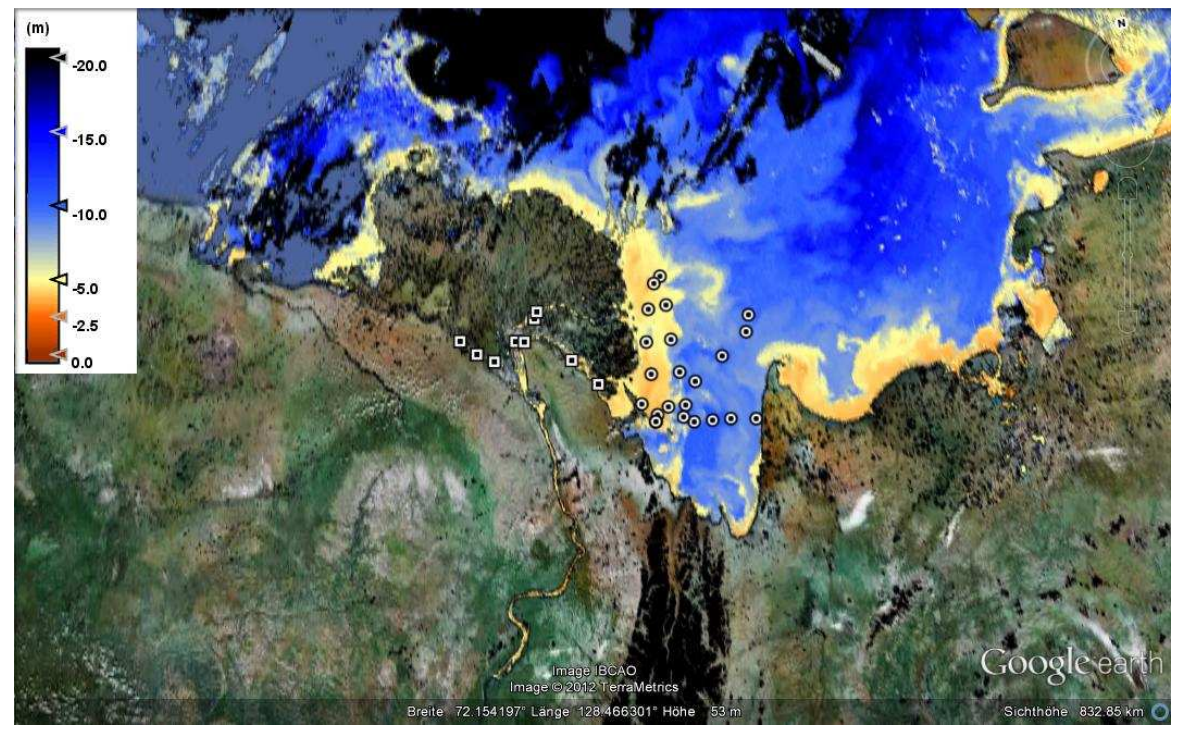

Fig. 5. Satellite image of 3 August 2012 from the ocean colour sensor MERIS indicating euphotic depth calculated as $Z_{\text {eu }}(\lambda)=4.6 / k(\lambda) m$, where $k$ is the diffuse attenuation coefficient in the PAR spectrum.

data have been archived in the online data repository Pangaea (http://pangaea.de). Supplementary image material from the phytoplankton counts has also been archived in the online plankton information repository PLANKTON*NET (http: //planktonnet.awi.de//index.php?thematicid=_2076).

\subsection{Numerical analyses}

Multivariate community analyses were carried out using Primer V6, a standard software for the analysis of biodiversity data which was specifically developed for the analysis of spatial and temporal patterns in complex data sets not amenable to normal parametric tests. As a first explorative technique to establish patterns in the phytoplankton communities, data were subjected to a non-parametric multidimensional scaling analysis. Prior to the analyses the data were $\log$-transformed $(\log (x+1))$ to account for the strongly zero-inflation in the data set (Clarke and Gorley, 2006). Based on the log-transformed data, a similarity matrix was constructed using Bray-Curtis similarities. Multidimensional scaling analysis was then carried out with the following settings: 25 restarts, a minimum stress of 0.01 , and Kruskal fit scheme 1 . The resulting configuration plots indicate distance between samples in terms of their underlying species composition, i.e. samples clustered together closely on the plot have a similar composition. The lines in the plot in Fig. 10 delineate the $60 \%$ similarity contours. These were obtained from a classification analysis on the same similarity matrix also used for the nMDS. The clusters found in the nMDS procedure were also used to subdivide the physicochemical data into groups for significance tests of differences in individual parameters (see results, Sects. 3.1 and 3.3.1).
Univariate pairwise or group comparisons of parameters (diversity, species counts in surface vs. subsurface samples) were also analysed using non-parametric methods. KruskalWallace median tests were implemented for tests between several independent groups and Mann-Whitney tests for tests between two groups (Statistica v10, Statsoft). Nonparametric methods were appropriate in the context of the present study as, due to the differences in lengths and depth of transects, a balanced number of samples per group was not a given. Regression analyses for the relationship between the two microzooplankton groups ciliates and dinoflagellates and different potential phytoplankton preys were conducted using the software SigmaPlot 10.0 (SYSTAT Software) under a linear model. The statistical significance of the linear regressions was tested by analysis of variance at a significance level of $p=0.05$. The data points for ciliates given in brackets result from a bloom (109200 cells L $\left.{ }^{-1}\right)$ of the mixotrophic/phototrophic ciliate Mesodinium rubrum and were excluded from the regression analyses (see Fig. 9a, $\mathrm{c}, \mathrm{e})$.

\subsubsection{Species-environment relationships}

To relate the species data set to the available environmental parameters and to establish the variables with the most explanatory power, a redundancy analysis was performed using CANOCO 4.5 software. The decision to carry out a redundancy analysis was taken after a preliminary detrended correspondence analysis (DCA), which determined a gradient length of 0.852 for the first ordination axis. Such a short gradient length indicates a linear relationship between response (i.e. species) and explanatory variables (environmental factors) (Leps and Smilauer, 2007), in which case a linear 

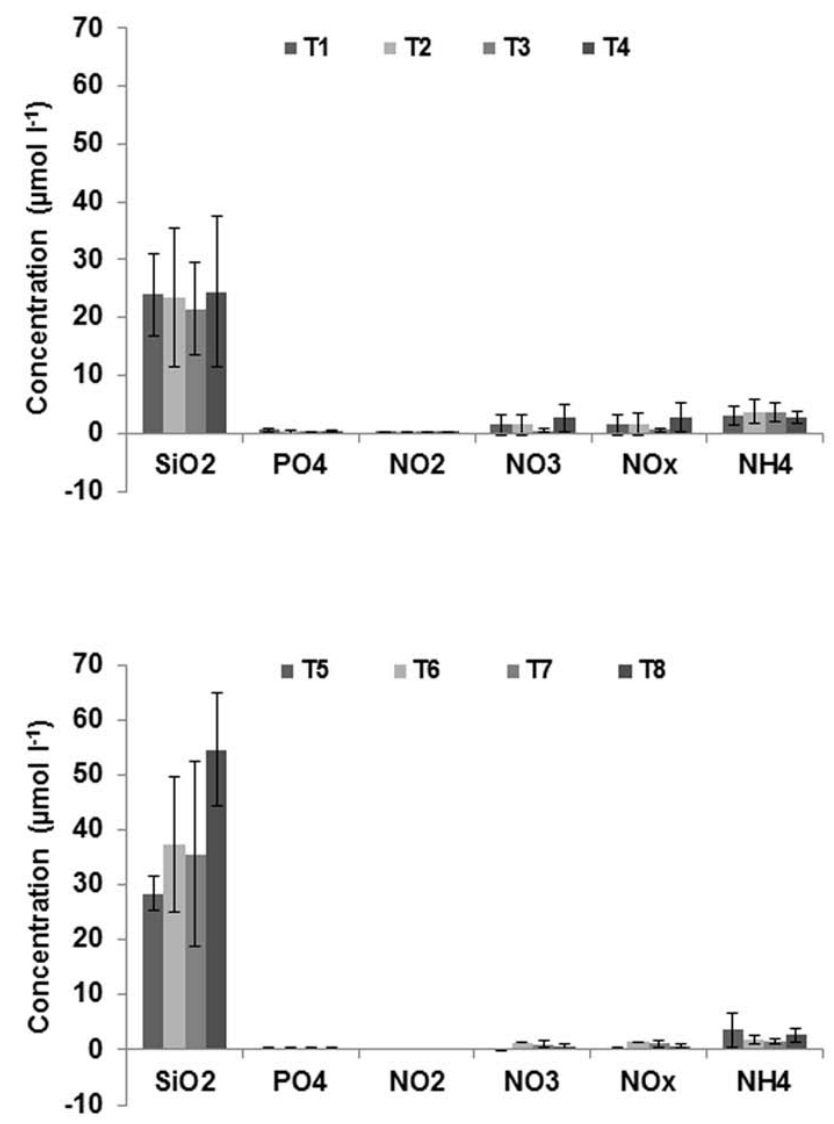

Fig. 6. Concentrations of inorganic nutrients in (a) the Lena Delta transects $(\mathrm{T} 5=$ Olenek channel, T6 $=$ Trofimov channel, T8 $=$, Bykov channel, and (b) the coastal transects T. Values were pooled across the stations in each transect. Error bars indicate the standard deviation for the stations per transect.

method such as principal component analysis (PCA) or redundancy analysis are the most appropriate techniques. Data were $\log +1$ transformed prior to the analysis. To further test which physico-chemical factors are most relevant in determining the multivariate species patterns, a further Primer routine was also performed known as BEST (Bio-Env STepwise). BEST finds the best match between multivariate patterns in the sample matrix and the matrix of environmental parameters by matching sites in the data sets using a Spearman rank correlation method. Nine environmental variables and the complete species similarity matrix were included in the analysis. The similarity matrices were constructed using Bray-Curtis similarity for the species data set and Euclidean distance for the environmental data set. Of the two analysis tools available, the BIO-ENV tool was chosen for the present analysis. This tool carries out a full analysis of all possible variable combinations as opposed to stepwise tests (Clarke and Gorley, 2006).

\subsubsection{Further relationships}

As a means of estimating the strength of stratification at a given station, a simple stratification index was devised whereby the difference in temperature and salinity between the surface and deepest samples were calculated as

Stratification strength $=\left(T_{\text {surface }}-T_{\text {bottom }}\right) / D$,

where $T$ is the temperature and $D$ the depth. For a completely mixed water column this results in an index value of zero. This is of course an oversimplification as the true relationship between temperature change and depth is not linear. The aim was simply to indicate the degree of change in temperature and salinity and therefore strength of stratification between top and bottom layer of water.

Moreover, the Shannon diversity was calculated for the complete species data set at each station. Shannon diversity $(H)$ was calculated as

$H=\sum_{i=1}^{R} p_{i} \log p_{i}$,

where $p_{i}$ is the proportion of individuals belonging to the $i$-th species in the data set.

\section{Results}

\subsection{Hydrography of the coastal region}

The surface plots of temperature, salinity, oxygen and $\mathrm{pH}$ (Fig. 2a-d) provide a first indication of the complexity of the coastal hydrography in the Lena region of freshwater influence. Salinity, $\mathrm{pH}$ and temperature showed a separation into two zones, a near coastal region characterized by the outflow from two of the river channels (Bykov and Trofimov; see black arrows in Fig. 2a) and a second zone further offshore. The nearshore hydrographic region (particularly transect 3 ) had a salinity close to zero and a slightly lower $\mathrm{pH}$ than the region further offshore (coastal transects 1,2 and 4). An exception was the region just north of Bykov peninsula (corresponding to stations T4-1004 and T3-1002), where salinity was approximately 2 . Oxygen concentrations, on the other hand, were rather uniform in the surface waters with percentages in excess of $90 \%$ at all stations.

The two regions discernible in the surface plots showed striking vertical differences. Transect 1 , with the exception of the station closest to the shore (T1-1001), was strongly stratified throughout (Fig. 3a-b). The same was true for transect 2 . The thermocline in these two transects was located at a depth of 4-6m and 5-7 m respectively. The transition was often very sharp with decreases in temperature of up to $4^{\circ}$ within $1 \mathrm{~m}$ of the water column (see also stratification index in Fig. 4a). In all of the shallow stations $(<5 \mathrm{~m}$ depth), bottom temperatures did not sink below $10^{\circ} \mathrm{C}$, while in the deep sites depths greater than $9 \mathrm{~m}$ displayed temperatures below $0^{\circ} \mathrm{C}$ (Fig. 3a, c, g). Although the CTD profiles of 

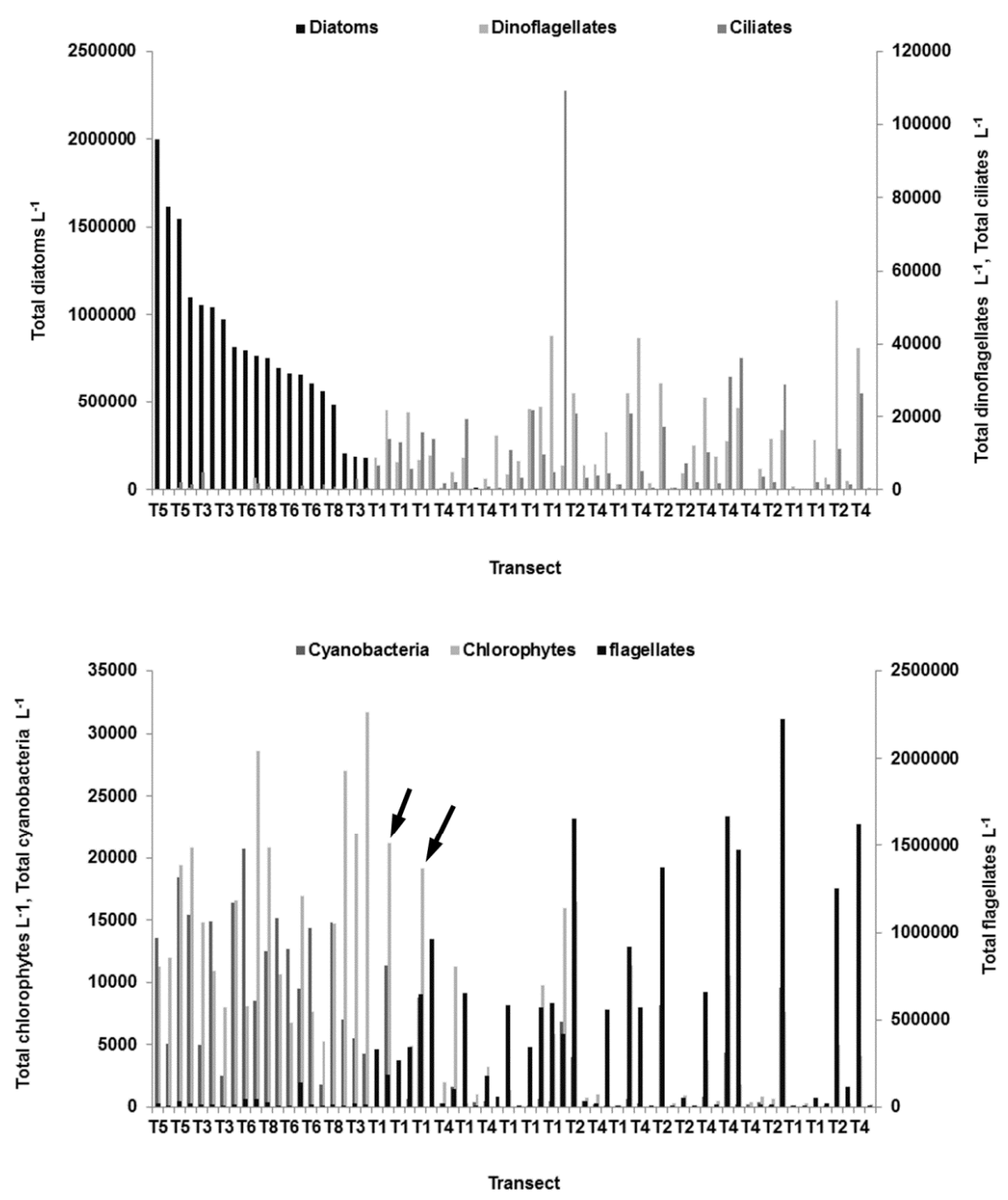

Fig. 7. Abundance of the principal plankton groups at all stations and transects: (a) diatoms (black bars), dinoflagellates (light grey bars), ciliates (dark grey bars); (b) flagellates (black bars), cyanobacteria (dark grey bars) and chlorophytes (light grey bars). Stations were sorted along decreasing diatom abundance, which gave rise to a grouping of the Lena Delta sites followed by the coastal sites. Data are shown across the whole data set, i.e. including both surface and subsurface samples, $n=66$. Arrows are pointing to coastal stations on T1 with particularly high numbers of chlorophytes.

the stations in transect 3 appeared otherwise well-mixed, the top $50 \mathrm{~cm}$ were approximately $1.5^{\circ}$ colder than the underlying water column in three of the stations. These stations, although well mixed, had therefore a negative stratification index. The northernmost station in transect 3 was colder and more saline throughout, indicating a transition to different water masses (Fig. 3e-f). The vertical changes in temperature and salinity are summarized in the plots of the stratification index (Fig. 4a-b).

Lastly, transect 4 was strongly stratified with an abrupt transition from surface waters $\left(6-10^{\circ}\right)$ to the waters below the thermocline, which had temperatures at or even slightly below zero. The different water masses in transect 4 were demonstrated even more clearly by the salinity profile, which indicated the extent of the Lena River plume (freshwater) northwards and at the same time the intrusion of saline bottom waters in the northernmost station (bottom salinity 21.68 at Station T4-1005). The heterogeneity of the sampling area was also evident in the supporting satellite imagery, which indicated euphotic depths of less than $5 \mathrm{~m}$ for the stations in transect 3 (approximately corresponding to the depth of the water) and approximately $10 \mathrm{~m}$ in transects 1 and 2 (approximate depth of thermocline) (Fig. 5).

The physico-chemical parameters were grouped into a "delta" and a "coast" group as well as into transect groups and were tested individually for significant differences 


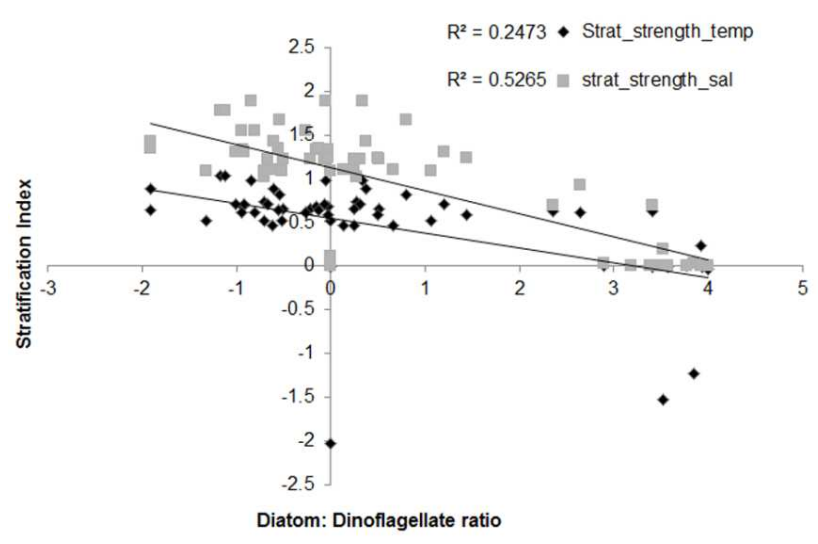

Fig. 8. The relationship between stratification index and diatom to dinoflagellate ratio. A value of zero in the stratification index means no stratification at all. Positive values show successively stronger stratification. Negative values indicate inverse stratification: dark marks $=$ temperature stratification, grey marks $=$ salinity stratification, $n=61$.

using Kruskal-Wallis and Mann-Whitney $U$ tests respectively. For the physical parameters temperature and salinity and the derived stratification indices, tests were significant at the $5 \%$ level for both the Mann-Whitney test based on the two larger regions (temperature stratification: $Z=-4.981, p<0.005$; salinity stratification: $Z=$ $-6.144, p<0.005$; temperature: $Z=5.23, p<0.005$; salinity: $Z=-5.38, p<0.005)$ and for the more detailed analysis based on transects (Kruskal-Wallis analyses were temperature stratification: $\mathrm{H}_{(6, N=58)}=38.022, p<0.005$; salinity stratification: $\mathrm{H}_{(6, N=61)}=40.43, p<0.005$; temperature: $\mathrm{H}_{(6, N=60)}=24.98, p=0.003$; salinity: $\mathrm{H}_{(6, N=62)}=$ $30.001, p<0.005)$. The relationships between these physical conditions and the biological community will be described in Sect. 3.3.1.

\subsection{Nutrient dynamics}

Nutrient concentrations were examined for both the Lena Delta proper and the coastal region. Concentrations of nitrate and phosphate were low in both the Delta and coastal stations. Significant differences only occurred in the concentrations of silicate. Silicate concentrations appeared to be generally lower in the coastal transects (varying between average values of $21.5 \mu \mathrm{mol} \mathrm{L}^{-1}$ in transect 1 and $24.5 \mu \mathrm{mol} \mathrm{L}^{-1}$ for transect 4 (values averaged across all stations per transect) but the difference was only significant on the basis of delta vs. coastal sites as defined by the multivariate analyses (Mann-Whitney $U$ test: $Z=1.9 p=0.048$ ). No significant differences were found when differences between transects were compared. However, despite the differences between coastal and Lena stations, the regression analysis, pooling data from all stations and depths, revealed no significant rela- tionship between silicate concentrations and salinity (regression analysis: $\left.F_{1,72}=0.31, p=0.57\right)$. There was, however, a significant increase in phosphate concentration $\left(F_{1,57}=\right.$ 22.958, $y=0.536 x+0.26, p<0.005)$ and nitrate concentration $\left(F_{1,57}=71.872, y=0.747 x+0.198, p<0.005\right)$ in combination with salinity, although this was also driven by the often higher nutrient concentrations in the more saline deep waters.

In the delta transects (transects 5 to 8), concentrations of silicate were not only significantly higher than in the coastal transects but also exhibited considerable differences between the different channels. The highest average concentrations occurred in Bykov channel (transect 8, $48.5 \mu \mathrm{mol} \mathrm{L}^{-1}$ on average) and in the Trofimov channel (transect 6 , average silicate concentration of $37.4 \mu \mathrm{mol} \mathrm{L}-1)$, both of which discharge into coastal waters within the sampling area (transect 3) (Fig. 6a, b).

\subsection{Plankton community composition and diversity}

Overall, 133 taxa or taxon groups from six broader groups were recorded: three autotrophic groups (diatoms, cyanobacteria and chlorophytes) and three groups containing both heterotrophic and autotrophic/mixotrophic components (dinoflagellates, ciliates and flagellates). Flagellates were grouped as such on the basis of morphology. These contained cryptophytes and crysophytes, but also prasinophytes, which taxonomically also belong to the chlorophytes. However, for the analyses they were grouped with the total flagellates due to their potential role as food for microzooplankton grazers. Taking a broad view, comparing overall differences between delta and coastal transects, the most striking difference was the shift from diatom and chlorophyte dominance in the delta to dinoflagellate, ciliate and flagellate dominance in the coastal transects, with the exception of transect 3, which captured the outflow from Bykov and Trofimov channels going north and therefore resembling the delta communities very closely (Fig. 7a-b). The highest numbers of autotrophic organisms occurred in transects 3,5 and 8 , reflecting the river plume flowing northwards. Transect 2 on the other hand was dominated by mixotrophic and heterotrophic taxa, particularly dinoflagellates and ciliates such as Mesodinium rubrum. This transect was also characterized by large populations of flagellates, particularly crypotpytes and prasinophytes less than $10 \mu \mathrm{m}$ in length. This essentially separates the micro community spatially into predominantly autotrophic and heterotrophic/mixotrophic components respectively. Ordering the sites in Fig. 7 by decreasing diatom abundance gave rise to two groups of sites, with freshwater sites (delta transects and T3) on one hand and the coastal communities on the other. The most abundant taxa of the different groups are given in Table 2. The most abundant diatom taxa included typical freshwater diatom taxa such as Aulacoseira spp. and Asterionella formosa. These species dominated in the delta sites and transect 3 , but were replaced 

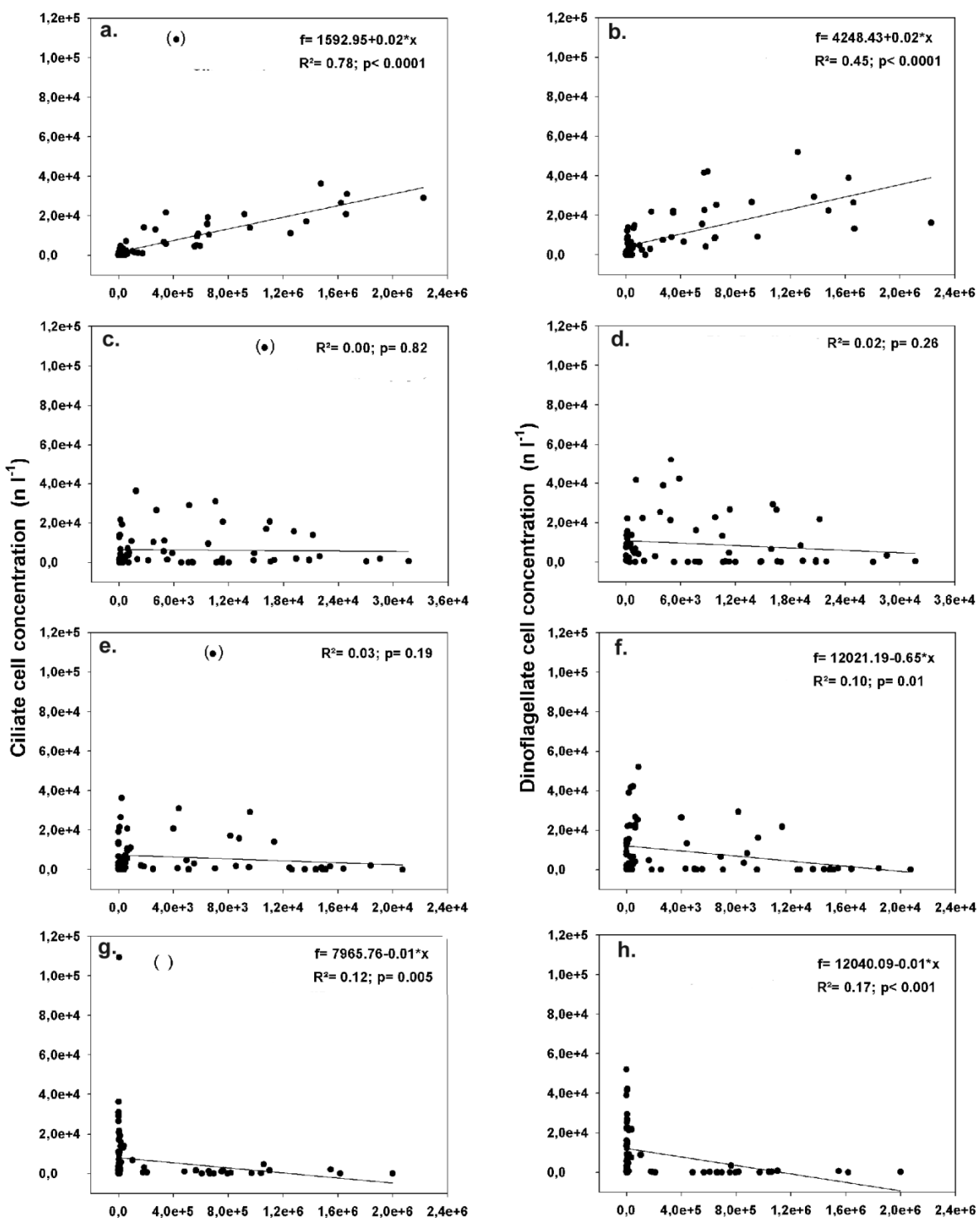

Phytoplankton cell concentration $\left(\mathrm{n} \mathrm{I}^{-1}\right)$

Fig. 9. Patterns of co-occurrence ciliates (graphs on the left) and dinoflagellates (on the right), with their potential food sources: total flagellates $(\mathbf{a}-\mathbf{b})$, chlorophytes $(\mathbf{c}-\mathbf{d})$, cyanobacteria $(\mathbf{e}-\mathbf{g})$, diatoms $(\mathbf{g}-\mathbf{h})$. The significance of the relationships was analysed by linear regression analysis. Regression equations for relationships significant at the $5 \%$ level are given in the relevant plots. All Lena Delta and coastal sites were included in the analysis, $n=66$.

byChaetoceros and Thalassiosira species in transect 1 and transect 2. Cyanobacteria were represented mainly by Aphanizomenon, Anabaena and Pseudanabaena species, although their abundance was usually at least an order of magnitude lower than the abundance of diatoms. The chlorophyceae were diverse with taxa in the family Selenastraceae, numerically most abundant and having the broadest distribution. The diatom: dinoflagellate ratio, which had also been calculated for all samples, showed a significant decrease with increasing calculated stratification strength (Fig. $8, F_{(1,58)}=$ 184.32, $p<0.0001, y=-0-88 x+1.25$ ). It was also sig- nificantly negatively correlated with salinity and temperature as well as positively correlated with silicate concentration $\left(F_{(1,56)}=10.613, p<0.0001, y=0.399 x+23.75\right)$ but was not affected by other inorganic nutrients.

The major plankton groups were also investigated in relation to potential predator-prey relationships. Figure 9 shows the results of regression analyses of the microzooplankton groups with potential prey groups. These analyses revealed highly significant positive relationships between total ciliate and flagellate abundance on one hand (Fig. 9a) and dinoflagellates and flagellates on the other. 
Table 2. Summary of the most abundant taxa in the different taxon groups together with their abundance averaged over all sites. Supplementary material of individual taxa is available at http://planktonnet.awi.de.

\begin{tabular}{|c|c|c|c|}
\hline Taxon groups & $\begin{array}{l}\text { Mean } \\
\left(\text { cells } \mathrm{L}^{-1}\right)\end{array}$ & $\begin{array}{l}\text { Peak abundance } \\
\left(\text { Cells } \mathrm{L}^{-1}\right)\end{array}$ & $\begin{array}{l}\text { Site of peak } \\
\text { abundance }\end{array}$ \\
\hline \multicolumn{4}{|l|}{ Diatoms } \\
\hline Aulacoseira spp. & 194580 & 1796240 & T5-1003 \\
\hline Asterionella formosa & 48141 & 292920 & T3-1004 \\
\hline Chaetoceros spp. & 3144 & 102480 & T1-1007-3 \\
\hline Aulacoseira granulata var angustissima & 3444 & 26080 & T5-1001-6 \\
\hline Aulacoseira granulata & 3342 & 33120 & T5-1002-18 \\
\hline \multicolumn{4}{|l|}{ Dinoflagellata } \\
\hline Gymnodiniaceae $<20 \mu \mathrm{m}$ & 5295 & 40680 & T4-1003 \\
\hline Unidentified thecate aff Heterocapsa & 1635 & 11920 & T4-1004 \\
\hline Amphidinium cf. extensum & 953 & 15600 & $\mathrm{~T} 2-1004$ \\
\hline Gymnodiniaceae $20-50 \mu \mathrm{m}$ & 811 & 11280 & T1-1003 \\
\hline Gymnodiniaceae $>50 \mu \mathrm{m}$ & 234 & 12400 & T1-1005-15 \\
\hline \multicolumn{4}{|l|}{ Chlorophyta } \\
\hline Monoraphidium spp./Koliella spp./Ankistrodesmus spp. & 3498 & 18200 & T1-1005 \\
\hline Actinastrum hantzschii & 909 & 5600 & T1-1002-4 \\
\hline Desmodesmus spp. & 743 & 3680 & T3-1003 \\
\hline Other Selenastraceae & 664 & 4650 & T2-1005 \\
\hline Monorhaphidium contortum & 591 & 1920 & T1-1004-4 \\
\hline Colonial chlorophytes (excl.Dictyospharium) & 269 & 640 & T3-1003,T5-1002-18 \\
\hline \multicolumn{4}{|l|}{ Cyanobacteria } \\
\hline Aphanizomenon spp. & 1286 & 8480 & T5-1001 \\
\hline Anabaena spp. (irregular coils) & 321 & 2240 & T5-1003 \\
\hline Pseudanabaena spp. & 1279 & 8400 & T8-1002-14 \\
\hline Unidentified filaments $<3 \mu \mathrm{m}$ & 463 & 2880 & T5-1001 \\
\hline Planktothrix spp. & 179 & 1360 & T5-1001 \\
\hline
\end{tabular}

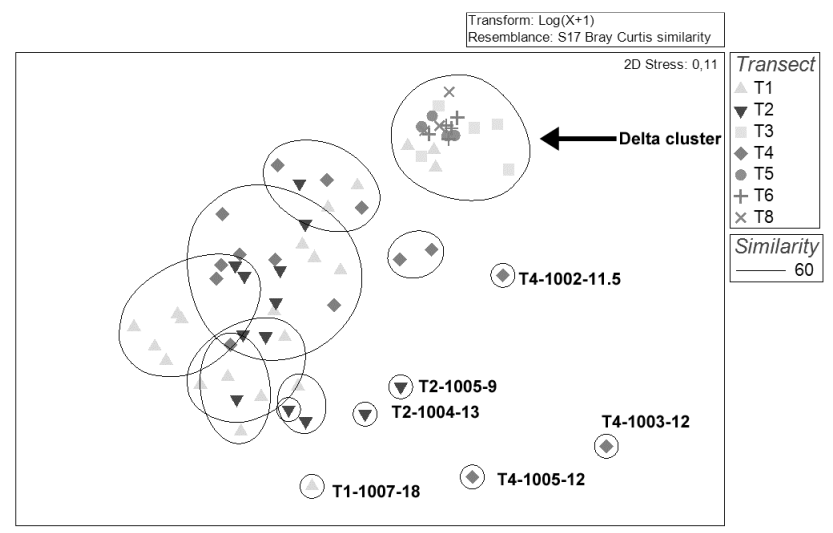

Fig. 10. Multidimensional scaling plot showing the distances (in terms of similarities) between the sites in the Lena Delta and coastal regions. All depths were included in the analysis. Black lines indicate $60 \%$ similarity contours. The arrow is pointing to the cluster containing all Lena Delta sites, T3 and three samples from stations 1 and 2 in transect 1 (the two stations closest to the coast).

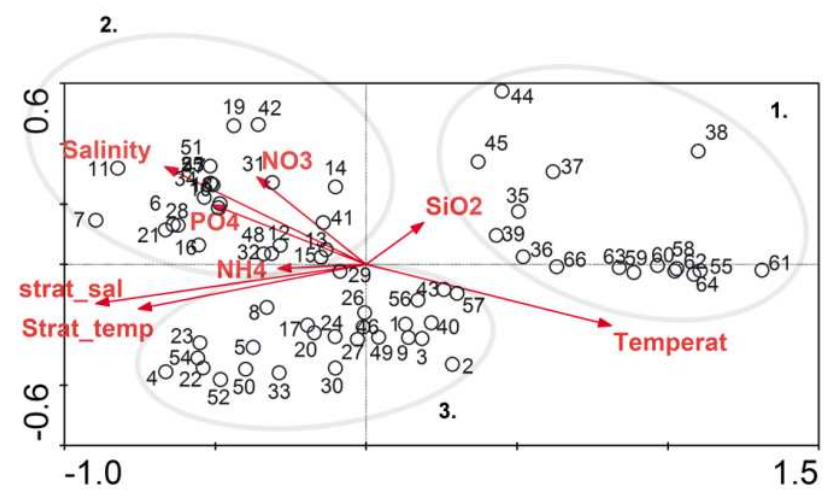

Fig. 11. Sample-environment biplot of the redundancy analysis carried out on all counted samples. For the calculation of the influence environmental factors, only those samples also used for the analysis of biological trends were included; site numbers: $1-22=\mathrm{T} 1,23-35$ $=\mathrm{T} 2,36-40=\mathrm{T} 3,41-55=\mathrm{T} 4,56-59=\mathrm{T} 5,60-64=\mathrm{T} 6,65-67$ $=\mathrm{T} 8$. 
Both microzooplankton groups were also significantly associated with diatoms (Fig. 9g-f), although in this case it was an inverse relationship, while no significant relationship was found between the two grazer groups and chlorophytes (Fig. 9c-d).

Overall, cell numbers and number of taxa were highest in the surface samples. Shannon diversity of the community on the other hand was significantly higher in subsurface than in surface samples (Table 3, Mann-Whitney $U$ test, $p=0.007)$. This was mainly due to the more even distribution of cell numbers across taxa, despite a significantly lower total number of taxa. However, no significant differences in diversity were found when separating data into individual transects (including all depths) (Kruskal-Wallace test, $\mathrm{d} f=6, p=0.11$ ) or on the basis of the delta vs. coast sites (Mann-Whitney test, $p=0.86$ ). However, the number of species was significantly higher in the Delta than in the coastal stations (Mann-Whitney test: $Z=5.944, p<0.005$ ) and also significantly different between transects (KruskalWallis test, $\left.H_{(1, N=66)}=35,41158, p<0.01\right)$.

\subsubsection{Multivariate phytoplankton community analyses}

The different hydrographic characteristics of the 4 transects were also reflected in the multivariate analyses considering the whole phytoplankton community. The "Delta" cluster was clearly separated from all other stations and contained all of the Delta stations, transect 3 and in addition 3 samples from transect 1 (stations T1-1001, T1-1002) (Fig. 10). The latter were located close to the outflow of the Bykov channel into the bay. They were characterized by higher concentrations of freshwater diatoms and chlorophytes than other transect 1 stations and the remainder of coastal stations in BuorKhaya Bay. They therefore grouped with the Delta cluster in the nMDS analysis. The remainder of the sites formed a heterogeneous group of small clusters. Six stations were exceptional in that they did not cluster with any larger group. Their species composition was more than $60 \%$ different from all other clusters and from each other. These samples represented the deepest samples from several of the coastal stations, all of which had a salinity of above 20 and a temperature below $1{ }^{\circ} \mathrm{C}$. The BEST analysis indicated that a combination of several factors, including stratification strength and absolute temperatures, could best describe these observed multivariate patterns (Spearman rank correlation 0.528). But interestingly, salinity as an absolute value rather than as part of the stratification index had little explanatory power in the analysis.

The second multivariate analysis, the redundancy analysis, related the biological communities to the environmental factors. The first two ordination axes explained $36.2 \%$ of the overall variation. This analysis showed the most important factors (denoted by the length of the arrow, Leps and Smilauer, 2007) to be the two calculated indices of stratification strength. Of the nutrients, phosphate and nitrate were the most important factors and they were closely correlated with salinity. Silicate concentration, on the other hand, as in the regression analyses of individual physic-chemical parameters, was only weakly correlated with salinity (Fig. 11). This setting of physico-chemical parameters gave rise to three distinct communities: (1) the true freshwater communities, rich in chlorophyte taxa and cyanobacteria. The driving factors here were higher temperatures in the riverine sites and to a lesser extent silicate concentrations. This cluster contained the Delta cluster already identified in the nMDS analysis and also contained stations from transect 4 . A second cluster was formed by those sites containing marine taxa such as Dinophysis. This pattern was driven by lower temperatures and increasing salinity. The third and largest cluster contained stations from several transects and was dominated by the subsurface samples (Fig. 11).

\section{Discussion}

\subsection{Hydrography}

The principal aim of this study was to establish a baseline for biodiversity and structure of the microplankton community and to relate these to hydrographic conditions in the Lena Delta and coastal Laptev Sea. The salinity and temperature patterns of the Lena Delta and adjacent areas proved very complex and were partitioned clearly into the actual region of freshwater influence, which was shallow and mixed or only weakly stratified, located on the nearshore shallow sill around the delta (transect 3); and the offshore deeper coastal waters, which were clearly stratified with respect to salinity and temperature, with the deep stratification leading to deoxygenation near the benthos in several stations (oxygen data not shown). The location of the thermo-haloclines and haloclines at depths between 5 and $10 \mathrm{~m}$ were in agreement with a study by Sorokin and Sorokin (1996) carried out in 1991.

The two regions could also be distinguished by satellite imagery, which showed considerable differences in euphotic depth between the river channels themselves and the coastal regions directly influenced by river discharge and re-suspension on the shallow delta sill around the Lena River delta on one hand and the coastal Laptev Sea region with deeper bathymetry on the other. The turbid waters of the river channels and on the shallow sill around the Lena River delta were limited to euphotic depths above $5 \mathrm{~m}$ in contrast to the more transparent deeper coastal waters with euphotic depths considerably deeper down to 8 to $10 \mathrm{~m}$ depth and considerably different nutrient concentrations measured particularly of silicate (Cauwet and Sidorov, 1996).

Stratification patterns in this region are known to be highly variable and to weaken/break completely during peak discharge after ice-off in spring (May/June), which can result in considerable variability in the size of the coastal area 
Table 3. Summary of the differences between key community parameters in the subsurface and subsurface samples. The subsurface samples were not further subdivided into different depths for the analysis, $N=66$ (

\begin{tabular}{lrrl}
\hline Site Factor & Surface & Subsurface & Mann-Whitney $U$ test, $p$ value \\
\hline No. of taxa & 42.9 & 33.9 & $p=0.03$ \\
Average abundance per site $\left(\mathrm{NL}^{-1}\right)$ & 1050000 & 345007 & $p<0.00001$ \\
Shannon diversity index & 1,194 & 1.631 & $p=0.007$ \\
\hline
\end{tabular}

still under a freshwater influence and therefore the degree to which riverine, terrigenous material can be exported to the open sea. Importantly, the satellite imagery also revealed the presence of a large meander, indicating a high degree of instability between the principal hydrographic zones on smaller than seasonal scales (Heim et al., 2013), making the interpretation of biological signals in the area even more difficult as the extent of these meanders is also related to the discharge magnitude from the major river branches. Longterm changes in discharge/run-off patterns from the Lena Delta, including Trofimov and Bykov channels, have already been shown, probably due to recent climate warming (Berezovskaya et al., 2004; Yang et al., 2002). These expected changes concomitant with the already high inherent variability of the system are likely to be reflected in the biological communities in the area.

\subsection{Biological communities: transition from freshwater to marine conditions}

The multivariate community analyses have shown the biological communities to mimic the salinity features thus showing the strong influence of riverine input on the coastal ecosystem with significant differences in species numbers between the Delta cluster and the coastal sites. All coastal areas directly influenced by the freshwater inputs had surface waters dominated by assemblages of freshwater phytoplankton, although in these areas the abundance of cyanophytes was markedly lower than in the river channels, possibly a consequence of the slightly increasing salinities in the coastal waters, which cyanobacteria are thought not to be able to tolerate. But Moisander et al. (2002) have shown that for cyanobacteria in brackish conditions, abundance is not necessarily determined by salinity. Light and nutrient conditions as well as stratification patterns are likely to be more important drivers. Particularly stratification patterns as the result of continued climate warming might be expected to significantly alter dominance patterns in the major phytoplankton groups in future (Taranu et al., 2012). At any rate, differences in surface salinities in the present study would also appear to be too small to explain the decline in abundance of cyanobacteria in the coastal phytoplankton community (Paerl, 1996). This was also confirmed by the results of the multivariate analyses where salinity alone was not an important driving factor in the BEST analysis. Salinity was a more important factor in the redundancy analysis but was also closely correlated with nutrient concentrations.

Nevertheless, the presence of all major taxonomic groups and particularly the persistence of some chlorophyte taxa in transect 3 and around the outflow of Bykov channel into Buor-Khaya Bay indicates the transitional nature of the coastal phytoplankton community between freshwater and marine conditions and it seems conceivable that in the only slightly increased salinities, and colder temperatures of the western part of Buor-Khaya Bay some chlorophyceae still actively contribute to primary production, although confirmation will require experimental investigations on the temperature and salinity tolerances of the species in question. It was particularly members of the family Selenastraceae that remained abundant in the bay (e.g. Monoraphidium, Selenastrum, Ankistrodesmus). They were also 1 of only 4 chlorophyceae taxa identified in a previous study by Tuschling (2000) in one of their transects that was located just east of our transect 4 and seems to have captured remnants of the freshwater plankton community.

The still low concentrations of microzooplankton and thus probably low grazing pressure in the coastal areas of BuorKhaya Bay will, at least in theory, facilitate transport of phytoplankton cells to greater depth by sinking out and by transport to the open Laptev Sea. While no sediment studies were carried out in the present study, a previous study by Cremer (1999) showed that horizontal transport (judging by the extent to which typical freshwater diatom frustules were found in the sediment) might actually be relatively limited and this also seems to be corroborated by the plankton diversity data, which showed a replacement of the freshwater diatoms by brackish/marine taxa e.g. Thalassiosira and Chaetoceros and the appearance of marine dinoflagellates such Dinophysis spp. (but see Rachold et al., 2000). Sinking of phytoplankton particles within the bay would then become available for bacterial degradation and re-mineralization of nutrients within Buor-Khaya Bay fuelling the microbial loop (Azam et al., 1983). Earlier studies have shown that bacterial production/distribution is closely linked to chlorophyll concentrations, as they utilize phytoplankton derived carbon, in the form of DOC (Fuhrman et al., 1980; Teeling et al., 2012). Feeding relationships between microzooplankton and flagellates have previously been observed for numerous dinoflagellate and ciliate species including Mesodinium rubrum (Yih et al., 2004; Johnson et al., 2007), which was 
also an abundant ciliate in the present study. Total ciliate abundance (and to a lesser extent that of dinoflagellates) was also very tightly coupled to that of the total flagellates suggesting a predator-prey relationship. However, only concurrent counts of bacterial and phytoplankton abundance and the exact determination of proportions of autotrophic and heterotrophic nanoflagellates coupled with grazing experiments in situ will reveal the true nature and strength of these relationships. Limited horizontal transport and efficient recycling of nutrients in the Buor-Khaya system would, if conclusively proven, be a possible explanation for the seemingly high productivity of the coastal system (see Doerffer et al., 2013; Tuschling, 2000; Sorokin and Sorokin, 1996).

A marked feature of the coastal region was the low species richness in the dinoflagellate group. While this group also contained the highest number of unidentified species and only detailed studies using techniques such as scanning electron microscopy can reveal their true diversity, previous studies have also shown dinoflagellate diversity in the East Siberian and Laptev seas to be low compared to other Arctic regions (Okolodkov and Dodge, 1996). Considering that only $10 \%$ of extant dinoflagellate species are thought to occur in freshwater (Taylor et al., 2008), it is possible that this apparently low diversity is a consequence of greater freshwater influence in the coastal Laptev Sea as opposed to other regions of the Arctic Ocean. Even easily identifiable marine species found in previous studies such as Neoceratium arcticum and $N$. longipes or Protoperidinium species such as P. depressum (Tuschling, 2000) were never found in the present study. Other taxa representative of more oceanic conditions, such as Dinophysis, also only having occurred in stations further offshore is a further pointer to the entire sampling area still being transitional between fully marine and freshwater conditions.

Due to their sensitivity to different environmental conditions, dinoflagellates have also received attention as indicator species, i.e. species that, due to their set of environmental tolerances, only occur in particular areas and can therefore be used as sensitive tools for the management of the marine environment (Birk et al., 2012; Rovira et al., 2012). One of the simplest indicator systems currently in use is the diatom : dinoflagellate ratio. A decreasing ratio has often been interpreted as a sign of excessive nutrient inputs (Ninčević et al., 2009). In the present study, however, the ratio is not linked significantly to any inorganic nutrients other than silicate, which is not surprising. It was, on the other hand, correlated with stratification strength on the basis of both salinity and temperature. While this could potentially present a simple indicator (without a need of taxonomic knowledge) of the extent of freshwater influence in the coastal Laptev Sea, whether this index is reliable can only be determined on the basis of long-term observations covering a range of environmental settings, but it seems unlikely that it will be able to discriminate between a series of co-varying factors (e.g. salinity, phosphate and nitrate) as in the present study.

\section{Conclusions and recommendations}

The first key result of our investigation was a detailed taxonomic assessment of the phytoplankton community of the Lena Delta (133 taxa in total) for both the main river channels and the coastal region within the same cruise, thereby creating a taxonomic baseline for comparison with future studies. The second important result was that we could demonstrate the clear differences in community composition between freshwater, non-stratified riverine waters and the coastal stratified waters with abrupt transitions from freshwater to a more brackish water community. The data shown here are still only a snapshot of the environmental conditions, and several years' of data will be required to understand the natural variability in hydrography and its effects on the biological communities in the Lena Delta and southern Laptev Sea. However, the broader implications of these findings are already clear. Physical factors are of paramount importance in determining the composition of the phytoplankton communities with respect to the balance between major phytoplankton groups such as cyanobacteria and diatoms, with changes in discharge or chemical composition of the river water likely to determine the spatial extent to which freshwater plankton is exported into the Laptev Sea. Therefore, particularly the strength and temporal persistence of stratification coupled with continued measurements of inorganic nutrients and DOC will require detailed observation in future cruises to the Lena Delta (one cruise has already been completed in September 2013; a further cruise is planned for 2014) to understand its natural variation and the added impacts of a potential freshening of the system on phytoplankton community composition. An added focus should also be the light regime in the coastal areas. This has been investigated in the Lena itself (Doerffer et al., 2013) but not in detail in Buor-Khaya Bay, although turbidity/transparence might also change as a result of changes in discharge, likely causing varying transport rates of organic material into the coastal Laptev Sea from the Lena proper. Importantly, for an assessment of potential climate change effects, future studies should also include laboratory investigations of the environmental tolerances of key Arctic phytoplankton species (particularly cyano- and chlorophyceae). Only if these physiological parameters are known can the potential responses of these taxon groups to future environmental conditions be judged. At present such data are still largely lacking and they should be investigated as part of well co-ordinated interdisciplinary investigations of the physics, chemistry and biology of the Lena Delta and coastal Laptev Sea. 
Acknowledgements. Thanks are due to the ship crews and the organizers of the Lena Delta expedition in 2010. We are also grateful to T. Zohary and A. Alster for help with the identification of some of the phytoplankton species, particularly the chlorophyceae and cyanophyceae. Particular thanks are also due to K. Carstens for carrying out the nutrient and chlorophyll analyses. We are also grateful to our Russian collaborators at AARI St. Petersburg and at the Lena Delta Reserve in Tiksi. Without their help and logistics support our work would not have been possible.

Edited by: P. Overduin

\section{References}

Azam, F., Fenchel, T., Field, J. G., Gray, J. S., Meyer-Reill, L. A., and Thingstad, F.: The ecological role of water-column microbes in the sea, Mar. Ecol.-Prog. Ser., 10, 257-263, 1983.

Berezovskaya, S., Yang, D., and Kane, L. D.: Comparability analysis of precipitation and runoff trends over the large siberian watersheds, Geophys. Res. Lett., 31, L21502, doi:10.1029/2004GL021277, 2004.

Birk, S., Bonne, W., Borja, A., Brucet, S., Courrat, A., Poikane, S., Solimini, A., van der Bund, W., Zampoukas, N., and Hering, D.: Three hundred ways to assess europe's surface waters: An almost complete overview of biological methods to implement the water framework directive, Ecol. Indic., 18, 31-41, 2012.

Bussmann, I.: Distribution of methane in the Lena Delta and Buor-Khaya Bay, Russia, Biogeosciences, 10, 4641-4652, doi:10.5194/bg-10-4641-2013, 2013.

Cauwet, G. and Sidorov, I. S.: The biogeochemistry of lena river: Organic carbon and nutrient distribution, Mar. Chem., 53, 211227, 1996.

Charkin, A. N., Dudarev, O. V., Semiletov, I. P., Kruhmalev, A. V., Vonk, J. E., Sánchez-García, L., Karlsson, E., and Gustafsson, Ö.: Seasonal and interannual variability of sedimentation and organic matter distribution in the Buor-Khaya Gulf: the primary recipient of input from Lena River and coastal erosion in the southeast Laptev Sea, Biogeosciences, 8, 2581-2594, doi:10.5194/bg8-2581-2011, 2011.

Clarke, K. R. and Gorley, R. N.: Primer v6 user manual/tutorial, Primer-e ltd, Plymouth, 2006.

Cremer, H.: The diatom fora of the laptev sea (arctic ocean), Bibliotheca Diatomologica, 40, 1-168, 1998.

Cremer, H.: Distribution of diatom surface sediment assemblages in the laptev sea (arctic ocean), Mar. Micropaleontol., 38, 39-67, 1999.

Doerffer, R. and Schiller, H.: The meris case 2 water algorithm, Int. J. Remote Sens., 28, 517-535, 2007.

Doerffer, R. and Schiller, H.: Meris regional coastal and lake case 2 water project atmospheric correction atbd. Gkss-kof-merisatbd01, Institute of Coastal Research GKSS Research Center, Geesthacht, 42 pp., 2008.

Doerffer, R., Röttgers, R., Boersma, M., and Wiltshire, K. H.: A biooptical model for remote sensing of lena water, Biogeosciences, in press, 2013.

Doney, S. C.: Plankton in a warmer world, Nature, 444, 695-696, 2006.

Finlay, J., Neff, J., Zimov, S., Davydova, A., and Davydov, S.: Snowmelt dominance of dissolved organic carbon in high-latitude watersheds: Implications for characterization and flux of river doc, 33, Geophys. Res. Lett., L10401, doi:10.1029/2006GL025754, 2006.

Fuhrman, J. A., Ammerman, J. W., and Azam, F.: Bacterioplankton in the coastal euphotic zone: Distribution, activity and possible relationships with phytoplankton, Mar. Biol., 60, 201-207, 1980.

Genkal, S. I., Shchur, L. A., and Yarushina, M. I.: Diatoms of some water bodies in northeastern west siberia. Communication 1. Centrophyceae, Contemp. Probl. Ecol., 3, 386-394, 2010.

Gordeev, V. V., Martin, J. M., Sidorov, I. S., and Sidorova, M. V.: A reassessment of the eurasian river input of water, sediment, major elements and nutrients to the arctic ocean, Am. J. Sci., 296, 664691, 1996.

Gordeev, V. V.: River input of water, sediment, major ions, nutrients and trace metals from russian territory to the arctic ocean, in: The freshwater budget of the arctic ocean, edited by: Lewis, E. L., Kluwer, Amsterdam, 297-322, 2000.

Grasshoff, K.: Methods of seawater analysis, 1. ed., Verlag Chemie, Weilheim, 1976.

Heim, B., Abramova, E., Doerffer, R., Günther, F., Hölemann, J., Kraberg, A., Lantuit, H., Loginova, A., Martynov, F., Overduin, P. P., and Wegner, C.: Ocean Colour remote sensing in the Southern Laptev Sea: evaluation and applications, Biogeosciences Discuss., 10, 3849-3889, doi:10.5194/bgd-10-3849-2013, 2013.

John, D. M., Brook, A. J., and Whitton, B. A.: The freshwater flora of the british isles: An identification guide to freshwater and terrestrial algae, 2nd edition, Cambridge University Press, Cambridge, 2011.

Johnson, M. D., Oldach, D., Delwiche, C. F., and Stoecker, D. K.: Retention of transcriptionally active cryptophyte nuclei by the ciliate myrionecta rubra, Nature, 445, 426-428, 2007.

Kassens, H., Dmitrenko, I. A., Rachold, V., Thiede, J., and Timokhov, L.: Russian and german scientist explore the arctic's laptev sea and its climate system, EOS, 79, 317-323, 1998.

Kassens, H., Bauch, H. A., Dmitrenko, I. A., Eicken, H., Hubberten, H.-W., Melles, M., Thiede, J., and Timokhov, L.: Land-ocean system in the siberian arctic: Dynamics and history, in, Springer Verlag, Berlin, Heidelberg, 711 pp., 1999.

Knefelkamp, B., Carstens, K., and Wiltshire, K. H.: Comparison of different filter types on chlorophyll-a retention and nutrient measurements, J. Exp. Biol., 345, 61-70, 2007.

Kopylov, A. I. and Kosolapov, D. B.: The structure of the planktic microbial community in the lower reaches of the ob river near salkhard, Contemp. Probl. Ecol., 4, 1-7, 2011.

Leps, J. and Smilauer, P.: Multivariate analysis of ecological data using canoco, Cambridge University Press, Cambridge, 269 pp., 2007.

Lobbes, J. M., Fitznar, H. P., and Kattner, G.: Biogeochemical characteristics of dissolved and particulate organic matter in russian rivers entering the arctic ocean, Geochim. Cosmochim. Ac., 64, 2973-2983, 2000.

Lund, J. W. G., Kipling, C., and Le Cren, E. D.: The inverted microscope method of estimating algal numbers and the statistical basis of estimations by counting, Hydrobiologia, 11, 143-170, 1958.

Lyon, S. W. and Destouni, G.: Changes in catchment-scale recession flow properties in response to permafrost thawing in the yukon river basin, Int. J. Climatol., 30, 2138-2145, 2010. 
Moisander, P. H., McClinton III, E., and Paerl, H. W.: Salinity effects on growth, photosynthetic parameters, and nitrogenase activity in estuarine planktonic cyanobacteria, Microb. Ecol., 43, 432-442, 2002.

Ninčević, Z., Marasović, J., Grbec, B., Kušpilić, G., Matijević, S., and Matić, F.: Inter-decadal variability in phytoplankton community in the middle adriatic (kastela bay) in relation to the north atlantic oscillation, Estuar. Coast., 33, 376-383, 2009.

Nowinski, N. S., Trumbore, S. E., Schuur, E. A. G., Mack, M. C., and Shaver, G.: Nutrient addition prompts rapid destabilization of organic matter in an arctic tundra ecosystem, Ecosystems, 11, 16-25, 2008.

Okolodkov, Y. B. and Dodge, J. D.: Biodiversity and biogeography of planktonic dinoflagellates in the arctic ocean, J. Exp. Mar. Biol. Ecol., 202, 19-27, 1996.

Oliver, R. L. and Ganf, G. G.: Chapter 6: Freshwater blooms, in: The ecology of cyanobacteria: Their diversity in time and space, edited by: Whitton, B. A., and Potts, M., Kluwer Academic Publishers, Amsterdam, 149-194, 2000.

Paerl, H. W.: A comparison of cyanobacterial bloom dynamics in freshwater, estuarine and marine environments, Phycologia, 35, 25-35, 1996.

Polyakova, Y. I., Klyutkina, T. S., Novichkova, E. A., Bauch, H. A., and Kassens, H.: High-resolution reconstruction of lena river discharge during the late holocene inferred from microalgae assemblages, Polarforschung, 75, 83-90, 2006.

Rachold, V., Grigoriev, M. N., Are, F. E., Solomon, S., Reimnitz, E., Kassens, H., and Antonow, M.: Coastal erosion vs. Riverine sediment discharge in the arctic shelf seas, Int. J. Earth. Sci., 89, 450-460, 2000

Rovira, L., Trobajo, R., and Ibanez, C.: The use of diatom assemblages as ecological indicators in highly stratified estuaries and evaluation of existing diatom indices, Mar. Pollut. Bull., 64, 500$511,2012$.

Sorokin, Y. I. and Sorokin, O. Y.: Plankton and primary production in the lena river estuary and in the south-eastern laptev sea, Estuar. Coast. Shelf Sci., 43, 399-418, 1996.

Taranu, Z. E., Zurawell, R. W., Pick, F., and Gregory-Eaves, I.: Predicting cyanobacterial dynamics in the face of global change: The importance of scale and environmental context, Glob. Change Biol., 18, 3477-3490, 2012.

Taylor, J. R. and Ferrari, R.: Ocean fronts trigger high latitude phytoplankton blooms, Geophys. Res. Lett., 38, L23601, doi:10.1029/2011GL049312, 2011.
Taylor, F. J. R., Hoppenrath, M., and Saldarriaga, J. F.: Dinoflagellate diversity and distribution, Biodivers. Conserv., 17, 407-418, 2008.

Teeling, H., Fuchs, B. M., Becher, D., Kloclow, C., Gardebrecht, A., Behnke, C. M., Kassabgy, M., Huang, S., Mann, A. J., Waldemann, J., Weber, M., Klindworth, A., Otto, A., Lange, J., Hernhardt, J., Reinsch, C., Hecker, M., Peplies, J., Bockelmann, F. D., Callies, U., gerdts, G., Wichels, A., Wiltshire, K. H., Glöckner, F. O., Schweder, T., and Amann, R.: Substrate-controlled succession of marine bacterioplankton populations induced by a phytoplankton bloom, Science, 336, 608-611, 2012.

Thompson, P. A., Waite, A. M., and Mahon, K. M.: Dynamics of a cyanobacterial bloom in a hypereutrophic stratified weir pool, Mar. Freshwater Res., 54, 27-37, 2003.

Tomas, C. R.: Identifying marine phytoplankton, Academic press, San Diego, 858 pp., 1997.

Tuschling, K.: Phytoplankton ecology in the arctic laptev sea - a comparison of three seasons, Berichte zur Polar-und Meeresforschung/Reports on Polar and Marine Research, 347, 1-144, 2000.

Utermöhl, H.: Neue wege in der quantitativen erfassung des planktons (mit besonderer berücksichtigung des ultraplanktons), Verhandlungen der internationalen Vereinigung theoretischer und angewandter Limnologie, 5, 567-596, 1931.

Wehr, J. D. and Sheath, R. G.: Freshwater algae of north america: Ecology and classification, in: Aquatic ecology, edited by: H., T. J., Academic Press, 918 pp., 2003.

Wiltshire, K., Harsdorf, B. S., Smidt, B., Blöcker, G., Reuter, R., and Schroeder, F.: The determination of algal biomass (as chlorophyll) in suspended matter from the elbe estuary and the german bright: A comparison of high-performance liquid chromatography, delayed fluorescence and prompt fluorescence methods, J. Exp. Mar. Biol. Ecol., 222, 113-131, 1998.

Yang, D., Kane, D. L., Hinzman, L. D., Zhang, X., Zhang, T., and Ye, H.: Siberian lena river hydrologic regime and recent change, J. Geophys. Res., 107, 4694, doi:10.1029/2002JD002542, 2002.

Yarushina, M. I.: Composition and structure of phytoplankton in the water bodies of the taz river basin, Nauchnyi Vestnik, 1, 41-52, 2008.

Yih, W., Kim, H. S., Jeong, H. J., Myung, G., and Kim, Y. G.: Ingestion of cryptophyte cells by the marine photosynthetic ciliate mesodinium rubrum, Aquat. Microb. Ecol., 36, 165-170, 2004. 